\title{
The use of laboratory tests in the diagnosis of SLE
}

\author{
William Egner
}

Systemic lupus erythematosus (SLE) is a protean autoimmune disease where autoantibodies are frequently targeted against intracellular antigens of the cell nucleus (double and single stranded DNA (dsDNA and ssDNA, respectively), histones, and extractable nuclear antigens (ENAs). Most of these autoantibodies are not specific for SLE and might be produced non-specifically as a result of polyclonal B cell activation. This article will focus on the evidence base for the most commonly used laboratory assays for the detection of these autoantibodies. Updated American Rheumatism Association (ARA) criteria for the diagnosis of SLE include several autoantibodies (table 1). ${ }^{12}$ SLE is likely if four of 11 criteria are met over any time period. Importantly, the methods for detecting these antibodies are not specified by the ARA, and this article aims to highlight the fact that the particular assay used will crucially influence the interpretation of the test (table 2). Autoantibodies are usually polyclonal-of mixed isotype, affinity, and avidity - and are often directed against multiple targets. Different assays detect particular antibody properties, which are often quite different, and the clinical importance of this for pathogenesis or diagnosis is rarely fully understood. The use of laboratory tests in SLE is a perfect example of this dilemma. The prevalence of autoantibodies varies widely in cross sectional studies, perhaps partly as a result of such differences (table 3). Immunodiffusion (ID) detects high affinity antibodies, immunofluorescence (IIF) moderate and high affinity antibodies, and enzyme linked immunosorbent assay (ELISA) low and high affinity antibodies. Purified antigens might have contaminants, or might not contain the full complement of native proteins. Recombinant antigens might lack certain epitopes, have altered glycosylation or tertiary structure, or contain contaminating bacterial antigens. All assays require careful validation to determine whether they perform adequately for detecting human autoantibodies. An ideal test

Accepted for publication 14 December 1999 would be specific (detects only those with disease), sensitive (detects all those with disease), have a high positive predictive value (PPV)where most positives have disease, and a high negative predictive value (NPV) - where most negatives do not have disease. In addition, assay results may reflect disease activity, correlate with organ involvement, or predict relapse, thus allowing pre-emptive treatment. No test or test panel can currently perform all these tasks because increases in specificity usually lead to reciprocal decreases in sensitivity, and because some of the clinical features of SLE are not antibody mediated. Therefore, the information obtained from any test will reflect the types of antibody detected, the prevalence of the disease in the population being tested, and the question being asked of the test.

\section{Antinuclear antibodies (ANAs)}

Any antibody to nuclear components is an ANA. Most patients with ANAs do not have SLE, but most people with SLE have ANAs. The most common screening test is IIF on rodent liver or human epithelial (HEp2) tissue $^{3}$ although ELISA tests are available. ${ }^{45}$ Lupus erythematous cells simply represent nuclei opsonised by ANAs and are no longer used in diagnosis. Although ANAs are very sensitive for SLE, positive ANAs are common, especially in unwell elderly individuals..$^{6-8}$ Therefore, ANAs have low PPV for SLE in unselected populations or when present in low titres, ${ }^{69}$ and are not diagnostic. One in three healthy people have detectable ANAs on HEp-2 cells at a screening dilution of $1 / 40$ and one in 20 will be positive at $1 / 160$. HEp- 2 cells produce more positive ANAs than rat tissue, and some ANAs (for example, anticentromere antibodies) can only be reliably detected on HEp-2 substrate. Although "ANA negative" SLE is reported, ${ }^{10}$ it is not clear whether this is the result of a technical artifact or whether a subgroup of SLE exists. Most ANA negative patients are positive in DNA or ENA assays or when screened by IIF on a different substrate. ARA criteria refer to "abnormal" titres of autoantibodies, but there is no cut off value that will absolutely distinguish normality from autoimmune disease. In general, higher titres are more meaningful, particularly in young patients. ANA measurement is at best semiquantitative, and is poorly standardised between laboratories owing to the lack of suitable reference preparations. The precision and accuracy of the technique depends on the assay configuration, the quality control procedures, and the experience of the reader (table 4). Patterns might suggest antibody specificities but are not diagnostic (table 5). Most clinically relevant ANAs are IgG antibodies and the detection of $\operatorname{IgM}$ antibodies usually reduces the

ACA, anticardiolipin antibody; ANA, antinuclear antigen; dsDNA, double stranded DNA; FP VDRL, false positive venereal disease reference laboratory test; IIF, immunofluorescence; LA, lupus anticoagulant. 
Table 2 Common attributes of individual assay technologies used for the diagnosis and monitoring of SLE (all assays produce some false positive results)

\begin{tabular}{|c|c|c|c|}
\hline Assay & Problems & Advantages & Result \\
\hline IIF rodent tissue & $\begin{array}{l}\text { Subjective, Ro may be missed, } \\
\text { semiquantitative, pattern not diagnostic, } \\
\text { cannot detect cell cycle related patterns, not } \\
\text { specific }\end{array}$ & Cheap, can be isotype specific & $\begin{array}{l}\text { Semiquantitative end point titration or } \\
\text { qualitative result at screening titre }+ \\
\text { pattern }\end{array}$ \\
\hline IIF HEp-2 & $\begin{array}{l}\text { Subjective, Ro may be missed, } \\
\text { semiquantitative (poor precision), pattern not } \\
\text { diagnostic, not specific }\end{array}$ & $\begin{array}{l}\text { Cheap, recombinant Ro60 expression to } \\
\text { boost Ro sensitivity available, can be } \\
\text { isotype specific }\end{array}$ & $\begin{array}{l}\text { Semiquantitative end point titration or } \\
\text { qualitative result at screening titre }+ \\
\text { pattern }\end{array}$ \\
\hline $\begin{array}{l}\text { Ouchterlony double diffusion } \\
\text { (ID) }\end{array}$ & $\begin{array}{l}\text { Slow, crude antigens, subjective, qualitative, } \\
\text { requires experience, not isotype specific, some } \\
\text { false negatives }\end{array}$ & Specific, cheap & Positive or negative + antigen specificity \\
\hline $\begin{array}{l}\text { Countercurrent } \\
\text { immunoelectrophoresis } \\
\text { (CIE) }\end{array}$ & $\begin{array}{l}\text { Slow, crude antigens, semiquantitative, } \\
\text { requires experience, not isotype specific, some } \\
\text { false negatives }\end{array}$ & As ID, but more sensitive & Positive or negative + antigen specificity \\
\hline Haemagglutination & $\begin{array}{l}\text { Detects IgG and IgM, semiquantitative, } \\
\text { subjective, detects low affinity antibodies }\end{array}$ & Cheap & $\begin{array}{l}\text { Positive or negative }+ \text { semiquantitative } \\
\text { titre }\end{array}$ \\
\hline Immunoblotting (IB) & $\begin{array}{l}\text { Qualitative, may be insensitive for Ro, crude } \\
\text { antigen, labour intensive }\end{array}$ & $\begin{array}{l}\text { Sensitive, very specific for individual } \\
\text { antigens }\end{array}$ & Positive or negative + antigen specificity \\
\hline Immunoprecipitation (Farr) & $\begin{array}{l}\text { Radioactive, labour intensive, expensive, } \\
\text { technically difficult, no isotype specificity, } \\
\text { false positivity }\end{array}$ & $\begin{array}{l}\text { Quantitative, high specificity, detects } \\
\text { high affinity antibodies }\end{array}$ & $\begin{array}{l}\text { Quantitative result, potentially in } \\
\text { standardised IU/1 if reference } \\
\text { preparation available }\end{array}$ \\
\hline ELISA & $\begin{array}{l}\text { Detects low affinity antibodies, needs high } \\
\text { purity well defined antigens (native } v \\
\text { recombinant), false positivity }\end{array}$ & $\begin{array}{l}\text { Sensitive, variable, can be polyspecific or } \\
\text { IgG specific }\end{array}$ & $\begin{array}{l}\text { Qualitative or quantitative results, } \\
\text { potentially in standardised IU/1 if } \\
\text { reference preparation available }\end{array}$ \\
\hline
\end{tabular}

ELISA, enzyme linked immunosorbent assay; IIF, immunofluorescence.

clinical usefulness of the test. ${ }^{11}{ }^{12}$ Antibody class switching to IgG usually occurs in established autoimmunity, and many low titre, low affinity $\operatorname{IgM}$ autoantibodies are found in healthy individuals. The absence of ANAs at titres of $1 / 160$ or less makes SLE very unlikely. Approximately $10 \%$ of SLE like disease is drug induced and potentially reversible. However, drug induced ANAs are more common than disease, and careful interpretation of the possible clinical relevance of an ANA in this context is needed. Each laboratory should configure its protocol for an appropriate sensitivity/ specificity compromise, should perform adequately in local and national external quality assessment (EQA) schemes, and should not interpret results without reference to the clinical details. More specific and precise tests should be performed in ANA positive individuals to determine the autoantibody specificity (table 5).

\section{Anti-DNA antibodies}

dsDNA antibodies are associated with systemic lupus and nephritis, but not subacute cutaneous lupus or discoid lupus. The best method for detecting anti-dsDNA remains controversial $^{13-18}$ (table 4). The most common techniques in the UK are dsDNA ELISA, Crithidia luciliae IIF (CLIF), or Farr immunoprecipitation assays (table 2). Specific assays should be used for diagnosis, whereas sensitive assays might be more useful for monitoring. ${ }^{4}$ There are several difficulties in the detection of

Table 3 Frequency of serological positivity in SLE

\begin{tabular}{lll}
\hline & $\begin{array}{l}\text { \% Positive at any } \\
\text { stage of disease } \\
\text { (any assay) }\end{array}$ & Possible clinical association (see text) \\
\hline dsDNA & $30-70$ & Nephritis, disease activity \\
Sm & $20-40$ & Rarely seen outside SLE \\
RNP & $40-60$ & MCTD/overlap features \\
Ro & $10-15$ & Sjogren's/skin involvement/congenital heart block \\
Ribosomal P0, P1, P2 & $5-10$ & Neuropsychiatric SLE, disease activity \\
Histone & 30 & Drug induced SLE, idiopathic SLE, disease activity \\
ACA & $40-50$ & Risk of thrombotic complications/fetal loss/ITP \\
\hline ACA, anticardiolipin antibody; dsDNA, double stranded DNA; ITP; idiopathic
\end{tabular}

ACA, anticardiolipin antibody; dsDNA, double stranded DNA; ITP; idiopathic
thrombocytopenic purpura; MCTD, mixed connective tissue disease; RNP, ribonuclear protein.
anti-dsDNA, which apply to other autoantibodies, including:

(1) Substrate differences: many sources of mammalian and non-mammalian DNA are used, but each might detect a different set of antibodies.

(2) The isotype of antibody detected: assays might detect different antibody isotypes (IgG, IgA, IgM, or any combination). All isotypes are detected by Farr assays, ELISA, or CLIF, which use polyspecific antisera. A positive polyspecific assay might have a different clinical relevance to that of an IgG specific assay. ${ }^{19}{ }^{20}$ IgM antidsDNA detected by ELISA might not be specific for SLE. ${ }^{20} 21$

(3) Antibody affinity: high affinity antidsDNA might be more relevant to SLE pathogenesis, particularly in nephritis. Low affinity antibodies are not detected by Farr assays, but are detected by ELISA. ${ }^{22-29}$

(4) Assay specific parameters: each assay has known causes of false positivity. For example, $\mathrm{C}$ reactive protein (CRP) or ssDNA contamination in the Farr; lipoprotein-IgG complexes in CLIF; antibodies to linkers in ELISA. Contamination with ssDNA leads to overestimation of anti-dsDNA titres, because antidsDNA antibodies regularly bind ssDNA, but ssDNA antibodies are not specific for SLE. ${ }^{30}$ This might not be important for monitoring disease activity because ssDNA might reflect the overall antinucleosome immune responses, ${ }^{31}{ }^{32}$ but it might reduce the diagnostic usefulness of an assay because ssDNA antibodies are not specific for SLE.

(5) Problems with standardisation and calibration: an assay has to be precise (give the same result on the same serum every time) to enable successful monitoring of serial titres. An assay should be accurate and produce the same result as other assays on all serum samples to enable comparison between different centres. An international reference preparation (IRP) for anti- 
Table 4 The clinical usefulness of commonly used autoantibody assays in SLE

\begin{tabular}{|c|c|c|c|c|c|}
\hline $\begin{array}{l}\text { Test (EQA } \\
\text { scheme?) }\end{array}$ & Technique & Diagnostic specificity & Clinical usefulness & Use in monitoring activity & $\begin{array}{l}\text { Evidence } \\
\text { base }\end{array}$ \\
\hline \multirow[t]{3}{*}{ ANA (EQA+) } & IIF rodent tissue & $\begin{array}{l}\text { Moderate for homogenous or speckled } \\
\text { pattern at } \geqslant 1 / 160 \text { in selected patients, } \\
\text { IgG only }\end{array}$ & Initial screen for further testing & Poor (semiquantitative) & Extensive \\
\hline & IIF HEp-2 & $\begin{array}{l}\text { Moderate for homogenous or speckled } \\
\text { pattern at } \geqslant 1 / 160 \text { in selected patients, } \\
\text { IgG only }\end{array}$ & Initial screen for further testing & Poor (semiquantitative) & Extensive \\
\hline & IIF ELISA & Unknown & Unknown & Possible & Limited \\
\hline \multirow[t]{4}{*}{ dsDNA (EQA+) } & Farr & Good, known causes of false positives & $\begin{array}{l}\text { Good for diagnosis and } \\
\text { monitoring }\end{array}$ & Useful in subset of patients & Extensive \\
\hline & Crithidia IIF & Good, known causes of false positives & Good for diagnosis & Poor (semiquantitative) & Extensive \\
\hline & ELISA & $\begin{array}{l}\text { Variable, assay dependent, IgG specific } \\
\text { good, known causes of false positives }\end{array}$ & $\begin{array}{l}\text { Assay dependent, good for IgG } \\
\text { specific }\end{array}$ & $\begin{array}{l}\text { Assay dependent, good for IgG } \\
\text { specific }\end{array}$ & Moderate \\
\hline & Nitrocellulose & Moderate & Moderate & No & Limited \\
\hline $\begin{array}{c}\text { Complement C3, } \\
\text { C4 (EQA+) }\end{array}$ & $\begin{array}{l}\text { Nephelometry/ } \\
\text { turbidometry }\end{array}$ & None & $\begin{array}{l}\text { Moderate, low C3 in renal } \\
\text { disease }\end{array}$ & $\begin{array}{l}\text { Useful in subset of SLE, serial } \\
\text { values essential }\end{array}$ & Extensive \\
\hline $\mathrm{CRP}(\mathrm{EQA}+)$ & $\begin{array}{l}\text { Nephelometry/ } \\
\text { turbidometry }\end{array}$ & None & $\begin{array}{l}\text { CRP usually low in active SLE } \\
\text { except in severe serositis }\end{array}$ & $\begin{array}{l}\text { Useful to distingiush infection } \\
\text { from SLE activity }\end{array}$ & Moderate \\
\hline \multirow{4}{*}{$\begin{array}{c}\text { ENA Ro/La/ } \\
\text { Sm/RNP } \\
(\text { EQA+) }\end{array}$} & $\begin{array}{l}\text { Immunodiffusion/ } \\
\text { CIE }\end{array}$ & $\begin{array}{l}\text { Good for } \mathrm{Sm} \text {, moderate for Ro/La, may } \\
\text { be poor for RNP }\end{array}$ & $\begin{array}{l}\text { Good for defining ANA } \\
\text { specificity }\end{array}$ & $\begin{array}{l}\text { No, except where disease has } \\
\text { evolved new features }\end{array}$ & Extensive \\
\hline & IB & Good, but may be insensitive for Ro & Good & No & Moderate \\
\hline & ELISA & $\begin{array}{l}\text { As ID/CIE but more sensitive for } \\
\text { Ro/RNP, less specific if low titre or IgM } \\
\text { positive }\end{array}$ & $\begin{array}{l}\text { Good for IgG antibody at } \\
\text { appropriate cut off }\end{array}$ & $\begin{array}{l}\text { No, except where disease has } \\
\text { evolved new features }\end{array}$ & Extensive \\
\hline & Haemagglutination & Poor, less specific, detects IgM & Poor & No, semiquantitative & Limited \\
\hline \multirow{3}{*}{$\begin{array}{l}\text { Antiphospholipid } \\
\text { antibodies } \\
\text { (ACA EQA+) }\end{array}$} & ACA ELISA & Poor, even for IgG antibodies & $\begin{array}{l}\text { Moderate, especially IgG } \\
\text { specific }\end{array}$ & Possible & Extensive \\
\hline & Anti- $\beta 2$ GP1 ELISA & Moderate for IgG antibodies & $\begin{array}{l}\text { Moderate, especially IgG } \\
\text { specific }\end{array}$ & Unknown & Moderate \\
\hline & $\begin{array}{l}\text { Lupus } \\
\text { anticoagulant }\end{array}$ & Poor & Moderate & Unknown & Moderate \\
\hline \multirow{2}{*}{$\begin{array}{l}\text { Antihistone } \\
\text { antibodies }\end{array}$} & ELISA & Poor, even for drug induced SLE & Poor & Possible & Limited \\
\hline & IB & Poor, even for drug induced SLE & Poor & No & Limited \\
\hline
\end{tabular}

$\mathrm{EQA}+$, UK external quality assessment scheme available.

ACA, anticardiolipin antibody; ANA, antinuclear antigen; $\beta 2 \mathrm{GP} 1, \beta 2$ glycoprotein 1 ; CIE, countercurrent immunoelectrophoresis; CRP, C reactive protein; dsDNA, double stranded DNA; ELISA, enzyme linked immunosorbent assay; ENA, extractable nuclear antigen; IB, immunoblotting; ID, immunodifussion; IIF, immunofluorescence; RNP, ribonuclear protein.

dsDNA (Wo80) is available to improve standardisation between assays (table 6), but there remains poor correlation between dsDNA assays in EQA schemes, even within a single technology. ${ }^{20}$ All laboratories should participate in EQA schemes and maintain adequate internal quality control procedures.

\section{DIAGNOSIS}

Farr assays are quite specific and well documented, but also detect high affinity IgM antidsDNA. IgG specific ELISA or CLIF methods are commonly used in UK laboratories, and may produce similar results to Farr assays. Polyspecific ELISAs also detect low affinity IgM antibodies of dubious clinical relevance and are less useful. ELISA results (particularly those detecting IgM) should be confirmed by IgG specific CLIF or Farr assays. ${ }^{33-36}$ CLIF is less likely than ELISA to detect low affinity
anti-dsDNA of uncertain clinical relevance, ${ }^{37-42}$ especially if IgG specific conjugates are used. Local validation of each assay is essential to ensure adequate diagnostic performance.

\section{MONITORING OF DISEASE}

Laboratory tests are no more effective than clinical review for detecting disease relapse, ${ }^{43-50}$ but are helpful in confirming the activity of SLE. The rapidity of clinical relapse clouds the interpretation of the few prospective studies available, and regular sampling every six to eight weeks would be required to predict relapse reliably. dsDNA antibodies rise in active disease and in the evolution of lupus nephritis in most patients. ${ }^{51-55} \mathrm{dsDNA}$ antibody assays can be negative early in disease, after treatment, or when the patient is in clinical remission; therefore, not all patients with SLE are seropositive at any one time. ${ }^{56}$ The absence of antibodies at any one time would not

Table 5 Common antinuclear antibody (ANA) HEp-2 patterns and their clinical use in SLE

\begin{tabular}{|c|c|c|}
\hline Pattern & Autoantibody association & Clinical association \\
\hline Homogenous & dsDNA, ssDNA, histones, nucleosomes, $\mathrm{Ku}$ & SLE, AICAH, and many non-pathological ANAs \\
\hline Rim/peripheral & dsDNA, laminin, nuclear pore & SLE/AICAH \\
\hline Speckled (coarse) & $\mathrm{RNP} / \mathrm{Sm}$ & SLE/MCTD \\
\hline $\begin{array}{l}\text { Speckled (fine) may be missed } \\
\text { on IIF owing to variable Ro } \\
\text { expression on tissue }\end{array}$ & $\mathrm{Ro} / \mathrm{La}$ (also cytoplasmic) & SLE/SCLE/scleroderma \\
\hline Speckled (centromere) & Centromere A, B, C kinetechore proteins & Primary Raynauds, scleroderma, SLE \\
\hline
\end{tabular}

The main use of the ANA pattern on screening is to determine the need for further antibody specificity testing or to distinguish possible false positive ELISA.

Patterns are not diagnostic, most homogenous or speckled ANAs have no detectable dsDNA or ENA antibodies.

AICAH, autoimmune chronic active hepatitis; dsDNA, double stranded DNA; ENA, extractable nuclear antigen; IIF, immunofluorescence; MCTD, mixed connective tissue disease; RNP, ribonuclear protein; SCLE, subacute cutaneous lupus erythematosus; ssDNA, single stranded DNA. 
Table 6 International reference preparations for autoantibodies

\begin{tabular}{ll}
\hline Reference preparation & Specificity \\
\hline WHO Wo80 & dsDNA 100 IU/ampoule \\
WHO1064 or MRC research standard A & Homogeous ANA 100 IU/ampoule \\
$66 / 233$ & \\
WHO1063 & nRNP \\
WHO1061 & IgM ANA 100 IU/ampoule \\
CDC reference preparations & dsDNA, La, U1-RNP, Sm, Ro, centromere, \\
& Scl70, Jo-1 \\
\hline
\end{tabular}

ANAs, antinuclear antibodies; CDC, Centers for Disease Control; dsDNA, double stranded $\mathrm{DNA}$; nRNP, nuclear ribonuclear protein.

exclude a previous diagnosis of SLE, and ARA criteria include events that occur sequentially over time. Prophylactic treatment on the basis of rising titres of anti-dsDNA cannot be widely justified at present, but rises in titre merit closer clinical monitoring for relapse. IgM and low affinity anti-dsDNA antibodies might be less specific for SLE. ${ }^{19} 5758$ High avidity IgA antibodies are seen in active SLE, ${ }^{59}$ but are no more helpful than IgG assays. Some IgG specific ELISAs have similar usefulness to the Farr assay, ${ }^{23}{ }^{60}$ but this requires validation on an assay by assay basis. It remains to be proved whether low affinity anti-dsDNA antibodies are specific for subclinical or mild SLE. ${ }^{29}{ }^{61}$

Anti-ssDNA activity might be useful in monitoring activity ${ }^{62}{ }^{63}$ but it is not clear that this offers any advantage over anti-dsDNA measurements and no EQA/IRP for ssDNA is available..$^{17} 60$

\section{Antihistone antibodies}

Around $50-80 \%$ of patients with SLE have IgG and IgM antihistone antibodies detectable by immunoblotting (IB) or ELISA. ELISAs are described that detect antibodies to total histones or to subfractions $(\mathrm{H} 1, \mathrm{H} 2 \mathrm{a}, \mathrm{H} 2 \mathrm{~b}, \mathrm{H} 3$, and $\mathrm{H} 4),{ }^{6465}$ but the clinical specificity is not well established for any subfraction. Titres of antihistone antibody might reflect disease activity, but are not specific for SLE and cannot distinguish drug induced SLE from idiopathic SLE. ${ }^{566}{ }^{67}$ Drug induced antibodies are often IgM and occur without any clinical manifestations.

\section{Antibodies to ENAs \\ ANTI-Ro/La ANTIBODIES}

Diagnosis

Antibodies to Ro(SS-A) and $\mathrm{La}(\mathrm{SS}-\mathrm{B})$ are found in SLE and Sjogren's syndrome. Neither is specific for SLE, but both are very useful when anti-dsDNA is absent. ${ }^{68} \mathrm{ID} / \mathrm{CIE}$ (countercurrent immunoelectrophoresis) assays were frequently used in the past, but are now superseded by more sensitive ELISA or IB assays (table 2). Some IB assays might be insensitive for anti-Ro. ELISAs are more sensitive for anti-Ro, anti-La, and anti-RNP, but are positive in other diseases also (table 4). ${ }^{369} 70$ Disease specificity is improved by excluding weak positives. Unlike anti-dsDNA, anti-ENA antibody affinity does not appear to be important, ${ }^{71}$ but IgG antibodies are of greater clinical relevance. ${ }^{12}$ Little is known about the importance of IgA or IgM anti-Ro. Ro exists in two forms: Ro52 and Ro60. In SLE, anti-Ro60 antibodies predominate, whereas both are present in Sjogren's syndrome. ${ }^{72}$ Ro60 contains conformational epitopes that are absent in some assay substrates. Newer enzyme immunoassays and western blotting are capable of discriminating antibodies to Ro52 and Ro60 individually, but it is not clear how clinically useful this will be. Bovine spleen is less sensitive than human substrate in ID/CIE, ${ }^{54}$ and can cause problems in detection.

\section{Monitoring}

There is little evidence that anti-ENA specificity or titres reflect SLE activity, ${ }^{68}{ }^{73}$ but anti-Ro is associated with cutaneous involvement in subacute cutaneous lupus erythematosus, ${ }^{74}$ and with congenital heart block (CHB).$^{75}$ Anti-Ro52 in isolation is associated with $\mathrm{CHB}$ but is not detected by assays containing only Ro- $60,{ }^{76}$ such as HEp-2000 cells.

Anti-La is rarely detected without anti-Ro ${ }^{77} 78$ because both proteins associate with a common type of human RNA called hYRNA. There is little evidence that anti-La is associated with reduced renal disease. Titres of anti-Ro and anti-La increase more slowly than anti-dsDNA in relapse and quantitative reporting is unlikely to be useful..$^{79}$ Standardisation of results between laboratories is still problematic in EQA schemes. Centers for Disease Control anti-ENA reference preparations of defined specificity, but no IRP with defined units, are available.

\section{Neonatal SLE and CHB}

Anti-Ro52, anti-Ro60, anti-La, or anti-Sm IgG is transferred across the placenta in the last trimester and on rare occasions can lead to pathology in the child. ${ }^{750-82}$ Serology can be performed on cord blood or the mother's blood antenatally, and intrauterine monitoring can be instituted in high risk seropositive pregnancies.

ANTIBODIES TO Sm/RNP

Diagnosis

High titre anti-Sm constitutes an ARA criterion for SLE and is highly SLE-specific, although low titre anti-Sm in ELISA/ immunoprecipitation assays has been reported in other diseases. ${ }^{53-85}$ Anti-Sm antibodies are rarely found without anti-RNP (ribonucleoprotein) $^{86}$ because both proteins associate with common snRNA species in the spliceosome. Anti-RNP is more common and less specific for SLE. ${ }^{83}{ }^{87}$ Anti-RNP ELISAs are more sensitive than ID, but ELISA and ID might be equivalent for anti-Sm ${ }^{70}{ }^{89}$ (table 2). Bovine thymus substrate has similar sensitivity to human thymus extract for $\mathrm{Sm} / \mathrm{RNP}$. The importance of antibody isotype or affinity is unknown. ${ }^{90}$

\section{Monitoring}

Anti-RNP or anti-Sm antibodies are not strongly associated with specific clinical features of SLE, outside mixed connective tissue disease (MCTD), ${ }^{73}$ 91-95 but anti-Sm might appear with disease evolution. ${ }^{96}$ Titres can fluctuate with disease activity and 
treatment, ${ }^{97-99}$ but serial monitoring does not effectively predict relapse. ${ }^{100} 101$

There are insufficient data on the more rare ENA specificities to justify routine clinical use.

Ribosomal $P$ antibodies

Anti-ribosomal antibodies detected by ELISA or IB are associated with neuropsychiatric SLE, ${ }^{102-106}$ but their predictive value is uncertain and controversial. ${ }^{107} 108$ Titres rise in active SLE. ${ }^{109}$ Data associating lymphocytotoxic antibodies with cognitive dysfunction are very limited. ${ }^{110}$

\section{Antiphospholipid antibodies}

Anticardiolipin antibodies (ACAs) of all isotypes are seen in $16-60 \%$ of patients with SLE. IgG ACAs ${ }^{11-115}$ are a risk factor for thrombosis and the antiphospholipid syndrome, but are controversial risk factors for renovascular events. ${ }^{116}{ }^{117}$ Not all ACA positive patients with SLE have an antiphospholipid syndrome and ACA negative patients can have thrombotic complications. ACAs might be an additional risk factor for pregnancy outcome in SLE. ${ }^{118} 119$ Titres vary with disease activity, perhaps explaining an association with severe renal disease. ${ }^{120121}$ EQA schemes reveal poor standardisation, despite the availability of reference materials for calibration.

IgG anti- $\beta 2$ glycoprotein 1 antibodies are more closely associated with thrombosis in the primary antiphospholipid syndrome and SLE, ${ }^{122}$ and approximately $25 \%$ of SLE patients may be positive. Other antiphospholipid antibodies are of uncertain importance including antiphosphatidyl serine, antiannexin V, and antithromboplastin.

Additional lupus anticoagulant testing (for example, dilute Russell's viper venom test or activated partial thromboplastin time) is essential because lupus anticoagulant might predispose to thrombosis, and might occur without ACAs. ${ }^{112}$ The reproducibility of the lupus anticoagulant test is variable and it cannot be used to monitor disease activity. ${ }^{123}$

\section{Acute phase proteins/cytokines}

The erythrocyte sedimentation rate is a sensitive but non-specific indicator of activity in SLE, and is slow to reflect changes in disease activity. CRP has a short half life and rapidly reflects acute inflammation. A high CRP can distinguish bacterial infection from active SLE, where the CRP is usually low, ${ }^{124-126}$ but CRP might be raised in severe lupus serositis. ${ }^{127}$ Soluble interleukin 2 receptor or tumour necrosis factor receptor values might reflect disease activity, but are not specific for SLE, and are of uncertain clinical relevance. ${ }^{128} 129$

\section{Complement}

Although immune complexes are seen in SLE, immune complex assays are poorly reproducible, non-specific, and rarely useful, ${ }^{130}$ except for cryoglobulins. Complement assays are occasionally useful. ${ }^{18}{ }^{28}{ }^{131-136} \mathrm{~A}$ single C4 is not informative and serial monitoring is necessary because C4 null alleles are common in SLE, so that the baseline $\mathrm{C} 4$ may be chronically low. ${ }^{137}$
SLE can also be active without causing changes in C3 and C4. ${ }^{48}$ Persistently low C3 is associated with chronic renal disease. ${ }^{138} 139$ Classical pathway assays (CH100/CH50) cannot distinguish deficiency from severe consumption, but can exclude early pathway complement deficiencies (C1, C2, or C4), which are associated with SLE. In contrast, C3 and C4 values are precise and economical, even if useful in some patients only.

Complement activation products $(\mathrm{C} 3 \mathrm{~d}$, C3a, C4a, C5a, iC3, C4d, Bb, C5b-9, and erythrocyte CR1) are raised in active disease, ${ }^{140-143}$ but assays to measure these molecules are not widely available and require special sample handling to a degree that makes routine clinical use impracticable.

\section{Anti-C1q antibodies}

Anti-C1q antibodies are detected by ELISA in $90 \%$ of patients with SLE, ${ }^{144}$ but are also found in membranoproliferative glomerulonephritis and rheumatoid vasculitis. High titres are associated with proliferative glomerulonephritis, ${ }^{145} 146$ but these antibodies are of limited clinical use.

\section{Anti-endothelial cell antibodies}

Anti-endothelial cell antibodies may reflect disease activity, ${ }^{147}$ but are poorly characterised.

Antineutrophil cytoplasmic antibodies

Antineutrophil cytoplasmic antibodies of all types are found in SLE and are not clinically relevant. ${ }^{148}$

\section{Summary}

ANA IIF is an effective screening assay in patients with clinical features of SLE and will detect most anti-ssDNA, anti-dsDNA, ENAs, and other autoantibodies. False positives are common. The clinical importance cannot be extrapolated from the ANA titre or pattern, although higher titres $(>1 / 160)$ are more likely to be important. HEp-2 cells are the most sensitive substrate for ANA detection, but this must be balanced against an increased incidence of insignificant positivity.

ANA positive samples should be subjected to more specific assays for the diagnosis of SLE. A combination of ENA (Ro/La/Sm/RNP) and dsDNA assays will detect most patients with SLE $^{18149}$ as long as the characteristics of the assays used are well understood. ESR and CRP measurements provide useful additional information. Sjogren's syndrome and MCTD will produce overlapping serology with SLE, and anti-dsDNA titres are sometimes seen in autoimmune hepatitis and rheumatoid arthritis. All results should be reported in the light of the clinical details, by an experienced immunologist. A suggested diagnostic protocol is outlined in fig 1 . The type of assay used crucially influences the predictive value of the tests. ELISA technology dominates routine laboratory practice, but tends to produce more false positive and true weak positive results, which may reduce the PPV of the test. This can be minimised by using IgG specific conjugates and careful assay validation. The NPV for SLE 


\section{Clinical suspicion of SLE}

ANA on HEp-2 at 1/80 or higher dilution (establish local threshold)
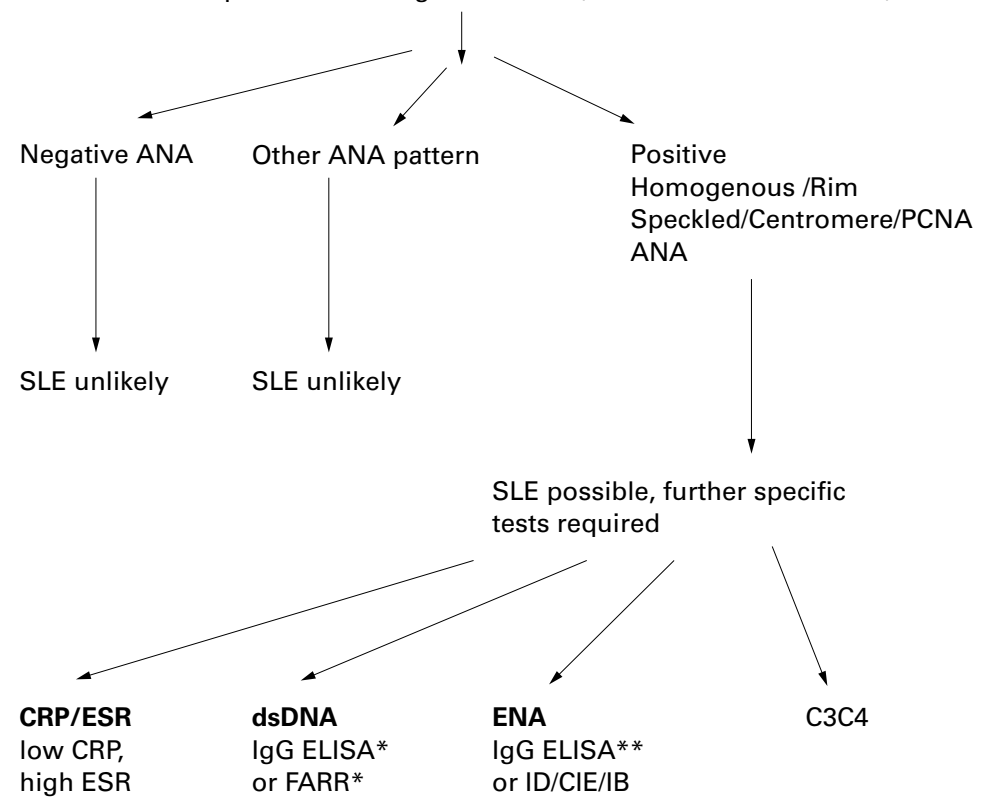

Figure 1 Suggested diagnostic protocol for investigation of suspected SLE. ${ }^{\star}$ Confirm weak positives or possible false positives by IgG CLIF; ** confirm weak positives or possible false positives by ID/CIE/IB. Antiphospholipid/lupus anticoagulant assays might be necessary if relevant clinical features of an antiphospholipid syndrome are present. ANA, antinuclear antibody; CIE, countercurrent immunoelectrophoresis; CLIF, Crithidia luciliae immunofluorescence; CRP, $C$ reactive protein; dsDNA, double stranded DNA; ELISA, enzyme linked immunosorbent assay; ENA, extractable nuclear antigen; ESR, erythrocyte sedimentation rate; ID, immunodiffusion; IB, immunoblotting; PCNA, proliferating cell nuclear antigen. important aspect of the appropriate use of laboratory assays is to become familiar with the limitations of the technology currently in use in your local laboratory, and to consult with your clinical immunologist in cases of doubt, preferably before commencing serological screening.

1 Tan E, Cohen A, Fries J, et al. The 1982 revised criteria for the classification of systemic lupus erythematosis. Arthritis the classification of system $1982 ; 25: 1271-7$.

2 Hochberg MC. Updating the American College of Rheumatology revised criteria for the classification of systemic lupus erythematosus. Arthritis Rheum 1997;40:1725.

3 van Venrooij WJ, Charles P, Maini, RN. The consensus work-shops for the detection of autoantibodies to intracellular antigens in rheumatic diseases. F Immunol Methods 1991;140:181-9.

4 Emlen W, O'Neill L. Clinical significance of antinuclear antibodies: comparison of detection with immunofluorescence and enzyme-linked immunosorbent assays. Arthritis Rheum 1997;40:1612-18.

5 Froelich CJ, Wallman J, Skosey JL, et al. Clinical value of an integrated ELISA system for the detection of 6 autoantibodies (ssDNA, dsDNA, Sm, RNP/Sm, SSA, and SSB). 7 bodies (ssDNA, dsDNA, Sm,
Rheumatol 1990;17:192-200.

6 Tan EM, Feltkamp TE, Smolen JS, et al. Range of antinuclear antibodies in "healthy" individuals [see comments]. Arthritis Rheum 1997;40:1601-11.

7 Ruffatti A, Calligaro A, Del Ross T, et al. Anti-doublestranded DNA antibodies in the healthy elderly: prevalence and characteristics. F Clin Immunol 1990;10:300-3.

8 Juby AG, Davis P. Prevalence and disease associations of certain autoantibodies in elderly patients. Clin Invest Med 1998;21:4-11.

9 Sheil WC, Jason M. Diagnostic associations of patients with antinuclear antibodies referred to community rheumatologists. F Rheumatol 1989;16:782-5.

10 Bohan A. Seronegative systemic lupus erythematosus. 7 Rheumatol 1979;6:534-40.

11 de Vlam K, De Keyser F, Verbruggen G, et al. Detection and dentification of antinuclear autoantibodies in the serum of normal blood donors. Clin Exp Rheumatol 1993;11:393-7.

12 Wahren M, Ringertz NR, Petterson I. IgM and IgG subclass distribution of human anti-Ro/SSA $60 \mathrm{kDa}$ autoantibodies. Scand F Immunol 1994;39:179-83.

13 Eilat D. The measurement of anti-DNA reactivity in the sera of patients with SLE: theoretical and practical considerations. Autoimmunity 1989;3:299-6.

is high for most assays but the PPV varies. Where necessary, laboratories should use crithidia or Farr dsDNA assays to confirm dubious ELISA dsDNA results, and ID/IB to confirm dubious ENA results.

For monitoring, a precise, quantitative assay is required. It is unclear whether the detection of $\operatorname{IgM}$ or low affinity antibodies has a role here. A combination of anti-dsDNA, C3, C4, CRP, and ESR assays provides the most useful clinical information. Anti-ssDNA assays are likely to be useful, and are potentially more robust than anti-dsDNA assays, but require more validation.

Local validation of individual assays and EQA participation is essential. Not all assays that apparently measure the same antibody specificities have equal clinical relevance, even within a single technology. Insufficient international or national reference preparations are currently available for many antibody specificities to enable effective standardisation. Quality assurance schemes reveal large differences in units reported by different assays for some analytes, even when calibrated against an IRP or equivalent reference preparation. Serial results can therefore only be compared from the same laboratory at present. Most autoantibodies increase during active disease, but few prospective data are currently available to justify treatment on the basis of rising titres. Further randomised prospective studies are required to examine the importance of antibody isotype and affinity in the monitoring of SLE by individual assay methods. The most
14 Isenberg DA, Dudeney C, Williams E, et al. Measurement of anti-DNA antibodies: a reappraisal using five different methods. Ann Rheum Dis 1987;46:448-56.

15 Kadlubowski M, Jackson M, Yap PL, et al. Lack of specificity for antibodies to double stranded DNA found in specificity for antibodies to double stranded DNA found
four commercial kits. $\mathcal{F}$ Clin Pathol 1991;44:246-50.

16 Chuan MT, Wu YC, Ang ET, et al. Clinical significance of anti-nDNA antibodies in ANA-positive systemic lupus erythematosus: comparison of the Farr radioimmunoassay and the Crithidia luciliae immunofluorescent technique. Chinese fournal of Microbiology and Immunology 1985;18: 15-24.

17 Okamura M, Kanayama Y, Amastu K, et al. Sigificance of enzyme linked immunosorbent assay (ELISA) for antibodies to double-stranded and single-stranded DNA in patients with lupus nephritis: correlation with severity of renal histology. Ann Rheum Dis 1993;52:14-20.

18 Clough JD, Chang RK. Effectiveness of testing for anti-DNA and the complement components iC $3 \mathrm{~b}, \mathrm{Bb}$, and $\mathrm{C} 4$ in the assessment of activity of systemic lupus C4 in the assessment of activity of syster
erythematosus. F Clin Lab Anal 1990;4:268-73.

19 Gripenberg M, Helve T. Anti-DNA antibodies of IgA class in patients with systemic lupus erythematosus. Rheumatol Int 1986;6:53-5.

20 Avina-Zubieta JA, Galindo-Rodriguez G, Kwan-Yeung L, et al. Clinical evaluation of various selected ELISA kits for the detection of anti-DNA antibodies. Lupus 1995;4:370-4.

21 Ehrenstein MR, Swana M, Keeling D, et al. Anti-DNA antibodies in the primary antiphospholipid syndrome (PAPS) [see comments]. Br f Rheumatol 1993;32:362-5.

22 Preud'homme JI, Rochard E, Gouet D, et al. Isotypic distribution of anti-dsDNA antibodies: a diagnostic evaluation by ELISA. Diagn Clin Immunol 1988;5:256-61.

23 Halliday GM, Salaman MR, Seifert MH, et al. Evaluation of an ELISA system for determination of class-specific an ELISA system for determination of class-specific antibodies to native and dena
Rheum Dis 1985;44:507-13.

24 Punsar S, Lee SR, LePage S, et al. Serial studies of IgG subclass and functional affinity of anti-dsDNA antibodies in systemic lupus erythematosis. F Autoimmun 1988;1:48394.

25 Sabbaga J, Pankewycz OG, Lufft V, et al. Cross-reactivity distinguishes serum and nephritogenic anti-DNA antibodies in human lupus from their natural counterparts in normal serum. F Autoimmun 1990;3:215-35.

26 Winfield J, Faiferman I, Koffler D. Avidity of anti-DNA antibodies in serum and glomerular eluates from patients with SLE. F Clin Invest 1977;59:90-6.

27 Leon S, Green A, Ehrlich G, et al. Avidity of antibodies in Rheum 1977;20:23-9. SLE: relation to severity of renal involvement. Arthritis 
28 Swaak AJG, Aarden LA, Statius van Eps LW, et al. Anti-dsDNA and complement profiles as prognostic guides in systemic 226 . 35 .

29 Smeenk R, van der Lelij G, Swaak T, et al. Specificity in systemic lupus erythematosus of antibodies to doublestranded DNA measured with the polyethylene glycol precipitation assay. Arthritis Rheum 1982;25:631-8.

30 Albani S, Massa M, Vioila S, et al. Antibody reactivity against single stranded DNA of various species in normal children and in children with diffuse connective tissue diseases. Autoimmunity 1990;8:77-80.

31 Misra R, Malaviya AN, Kumar R, et al. Clinical relevance of the estimation of antibodies to single stranded DNA in SLE. Indian $\mathcal{7}$ Med Res 1988;87:463-7.

32 Koffler D, Agnello V, Winchester R. Occurrence of single-stranded DNA in serum of patients with SLE and single-stranded DNA in serum of patients
other diseases. F Clin Invest 1973;52:198-4.

33 Werle E, Blazek M, Fiehn W. The clinical significance of measuring different anti-dsDNA antibodies by using the Farr assay, an enzyme immunoassay and a Crithidia luciliae immunofluorescence test. Lupus 1992;1:369-77.

34 James K, Meek G. Evaluation of commercial enzyme immunoassays compared to immunofluorescence and double diffusion for autoantibodies associated with autoimmune diseases. Am f Clin Pathol 1992;97:559-65.

35 Fisher-Smikle M, James OB. Diagnosis of systemic lupus erythematosus in Jamaica by Crithidia luciliae indirect immunofluorescence test. Trans R Soc Trop Med Hyg 1987; 81:255-6.

36 Hodinka L, Meretey K, Jancso A, et al. Antibodies to native DNA in connective tissue disease. A comparison of radioimmunoassay, counterimmunoelectrophoresis and indirect immunofluorescence on Crithidia luciliae substrate. Arch Immunol Ther Exp 1979;27:641-6.

37 Monier JC, Sault C, Bringuier JP. Discrepancies between 2 procedures for dsDNA antibody detection: Farr test and indirect immunofluorescence on Crithidia luciliae. $f$ Clin Lab Immunol 1988;25:149-52.

38 Tipping PG, Buchanon RRC, Riglar AG, et al. Detection of anti-DNA antibodies: a comparison between two Far assays, Crithidia luciliae and a human chromosoma substrate assay. Br F Rheumatol 1988;27:206-10.

39 Huber O, Greenberg ML, Huber J. Complement-fixing anti-double-stranded DNA with the Crithidia method: a better indicator of active SLE than anti-DNA with the Farr method. F Lab Clin Med 1979;93:32-9.

40 Henderson $\mathrm{T}$, Medsger TA, Jr, Sontheimer RD, et al. Specificity of the hydrochloric-acid-modified Crithidia luciliae immunofluorescence assay for detection of antibody to native DNA. Diagn Clin Immunol 1987;5:20-4.

41 Aarden L, de Groot E, Feltkamp T. Immunology of DNA III. Crithidia luciliae, a simple substrate for the determination of anti-dsDNA with immunofluorescent technique. Ann N Y Acad Sci 1975;254:505-8.

42 Kumar V, Krasny S, Beutner EH. Specificity of the Crithidia luciliae method for detecting anti-DNA antibodies. Effect of absorption for lipoproteins. Immunol Invest 1985;14 199-210.

43 Fortin PR, Abrahamowicz M, Danoff D. Small changes in outpatiens' lupus activity is better detected by clinical
instruments than by laboratory tests. $\mathcal{F}$ Rheumatol $1995 ; 22$ : 2078-83.

44 Petri M, Genovese M, Engle E, et al. Definition, incidence and clinical description of flare in systemic lupus erythematosus: a prospective cohort study. Arthritis Rheum 1991;34:937-44.

45 Bootsma H, Spronk P, Derksen R, et al. Prevention of relapses in systemic lupus erythematosus [published
erratum appears in Lancet 1995;346:516]. Lancet 1995; erratum app

46 Swaak AJ, Groenwold J, Bronsveld W. Predictive value of complement profiles and anti-dsDNA in systemic lupus erythematosus. Ann Rheum Dis 1986;45:359-66.

47 ter Borg EJ, Horst G, Hummel EJ, et al. Measurement of increases in anti-double-stranded DNA antibody levels as a predictor of disease exacerbation in systemic lupus erythematosus. A long-term, prospective study. Arthritis Rheum 1990;33:634-43.

48 Esdaile JM, Abrahamowicz M, Joseph L, et al. Laboratory tests as predictors of disease exacerbations in systemic lupus erythematosus. Why some tests fail. Arthritis Rheum 1996;39:370-8.

49 Kallenberg CG, Bootsma H, Spronk PE, et al. Laboratory tests as predictors of flares in systemic lupus tests as predictors of flares in systemic lupus erythematosus: comment on the article
ter]. Arthritis Rheum 1997;40:393-4.

50 Jonsson H, Nived O, Strufelt G. Outcome in systemic lupus erythematosus: a prospective study of patients from a defined population. Medicine 1989;68:141-50.

51 Smeenk R, Brinkman K, van den Brink H, et al. Antibodies to DNA in patients with systemic lupus erythematosus. Their role in the diagnosis, the follow-up and the pathogenesis of the disease. Clin Rheumatol 1990;9(suppl 1): $100-10$

52 Massa M, De Benedetti F, Pignatti P, et al. Anti-double stranded DNA, anti-histone, and anti-nucleosome IgG reactivities in children with systemic lupus erythematosus. Clin Exp Rheumatol 1994;12:219-25.

53 Swaak AJ, Groenwold J, Aarden LA, et al. Prognostic value of anti-dsDNA in SLE. Ann Rheum Dis 1982;41:388-95.

54 Clough JD, Barna BP, Danao-Camara TC, et al. Serological detection of disease activity in SLE. Clin Biochem 1992;25. 201-18.
55 Spronk PE, Limburg PC, Kallenberg CG. Serological markers of disease activity in systemic lupus erythematosus. Lupus 1995;4:86-94.

56 Gladman DD, Urowitz MB, Keystone EC. Serologically active clinically quiescent systemic lupus erythematosus: a discordance between clinical and serological features. Am $\mathcal{F}$ Med 1979;34:937-44.

57 Nossent JC, Huysen V, Smeenk RJ, et al. Low avidity ntibodies to dsDNA as a diagnostic tool. Ann Rheum Dis 1989;48:748-52.

58 Smeenk R, Hylkema M. Detection of antibodies to DNA: a technical assessment. Mol Biol Rep 1992;17:71-9.

59 Miltenburg AMM, Roos A, Slegtenhorst L, et al. IgA anti-dsDNA antibodies in systemic lupus erythematosus: occurence, incidence and association with clinical and laboratory variables of disease activity. $f$ Rheumatol 1993;20:53-8.

60 Sarvas H, Gripenberg M, Leirisalo-Repo M. Anti-DNA antibodies: the choice of assays for routine diagnostic work. Acta Pathol Microbiol Immunol Scand 1985;93:13-18.

61 Hahn B. Antibodies to DNA. N Engl f Med 1998;338:135968.

62 Heinzerling RH, Dziuba DS, Federyszyn HM, et al. Significance of levels of specific immunoglobulins to DNA in SLE patients' sera detected by solid phase radioimmunoassay. $\mathcal{F}$ Invest Dermatol 1979;72:55-8

63 Yu CL, Huang MH, Tsai CY, et al. The reactivity of sera from patients with systemic lupus erythematosus to seven different species of single and double stranded deoxyribonucleic acids. Clin Exp Rheumatol 1996;14:137-44.

64 Rubin R, Josli F, Tan E. A solid-phase radioimmunoassay for anti-histone antibodies in human sera: comparison with immunofluorescence. Scand F Immunol 1982;15:63-70.

65 Aitkaci A, Monier J, Mamelle N. Enzyme-linked immunosorbent assay for anti-histone antibodies and their presence in SLE sera. F Immunol Methods 1981;44:311-22.

66 Rubin W, Waga S. Anti-histone antibodies in systemic lupus erythematosus. f Rheumatol 1997;14(suppl 3):118-26.

67 Molden D, Klipple G, Peebles C, et al. IgM anti-histone H3 antibodies associated with undifferentiated connective tissue disease. Arthritis Rheum 1986;29:39-46.

68 Sanchez-Guerrero J, Lew RA, Fossel AH, et al. Utility of anti-Sm, anti-RNP, anti-Ro/SS-A, and anti-La/SS-B (extractable nuclear antigens) detected by enzyme-linked immunosorbent assay for the diagnosis of systemic lupus erythematosus. Arthritis Rheum 1996;39:1055-61.

69 Gordon T, Mavrangelos C, McCluskey J. Restricted epitope recognition by precipitin-negative anti-La/SS-B positive sera. Arthritis Rheum 1992;35:663-6.

70 Garcia Lerma JG, Mendoza AZ, Ramos MJ, et al. Evaluation of recombinant Ro/SSA, La/SSB, Sm, and U1 RNP autoantigens in clinical diagnosis [see comments]. $\mathcal{F}$ Clin Lab Anal 1995;9·52-8.

71 Gaither KK, Fox OF, Yamagata $\mathrm{H}$, et al. Implications of anti-Ro/Sjogren's syndrome antigen autoantibody in nor mal sera for autoimmunity. $\mathcal{F}$ Clin Invest 1987;79:841-6.

2 Slobbe RL, Pruijn GJM, Damen WGM, et al. Detection and occurence of the 60- and 52-kD Ro (SS-A) antigens and of autoantibodies against these proteins. Clin Exp Immunol 1991;86:99-105.

73 Clotet B, Guardia J, Pigrau C, et al. Incidence and clinical significance of anti-ENA antibodies in systemic lupus erythematosus. Estimation by counterimmunoelectrophoresis. Scand F Rheumatol 1984;13:15-20.

74 Lopez-Longo FJ, Monteagudo I, Gonzalez CM, et al. Systemic lupus erythematosus: clinical expression and anti-Ro/SSA response in patients with and without lesions of subacute cutaneous lupus erythematosus. Lupus 1997;6: $32-9$.

75 Buyon JP, Winchester R. Congenital complete heart block. A human model of passively acquired autoimmune injury.

76 Oshiro AC, Derbes SJ, Stopa AR, et al. Anti-Ro/SSA and anti-La/SSB antibodies associated with cardiac involvement in childhood systemic lupus erythematosus. Ann Rheum Dis 1997;56:272-4.

77 Harley J, Yamagata H, Reichlin M. Anti-La (SSB) antibody is present in some normal sera and is co-incident with Ro

78 Meilof JF, Veldhoven CH, Swaak AJ, et al. Production of anti-Ro/SSA and anti-La/SSB autoantibodies is closely coordinated in systemic lupus erythematosus and independent of anti-dsDNA production. F Autoimmun 1997;10: 67-75.

79 Schofield RH, Zhang F, Kurien BT, et al. Development of the anti-Ro autoantibody response in a patient with systemic lupus erythematosus. Arthritis Rheum 1996;39:1664-8.

80 Pilkington C, Taylor PV, Silverman E, et al. Agalactosyl IgG nd materno-fetal transmission of autoimmune neonatal upus. Rheumatol Int 1996;16:89-94.

81 Franco H, Weston W, Peebles C, et al. Autoantibodies directed against Sicca syndrome antigens in the neonat lupus syndrome. $\mathcal{A}$ Am Acad Dermatol 1981;4:67-72.

82 Sheth AP, Esterly NB, Ratoosh SL, et al. U1RNP positive neonatal lupus erythematosus: association with anti-L antibodies? Br f Dermatol 1995;132:520-6.

83 Maddison PJ, Skinner RP, Vlachoyiannopolous P, et al. Antibodies to nRNP, Sm, Ro(SSA) and $\mathrm{La}(\mathrm{SSB})$ detected by ELISA: their specificity and interrelations in connective tissue disease sera. Clin Exp Immunol 1985;62:337-45.

84 Pan LT, Tin SK, Boey ML, et al. The sensitivity and specificity of autoantibodies to the Sm antigen in the diagnosis of systemic lupus erythematosus. Ann Acad Med Singapore 1998;27:21-3. 
85 Sirota P, Firer M, Schild K, et al. Increased anti-Sm antibodies in schizophrenic patients and their families.
Progress in Neuro-psychopharmacology and Biological PsychiaProgress in Neuro-psychop
try 1993;17:793-800

86 Habets WJA, Hoet MH, Sillekens PTG, et al. Detection of autoantibodies in a quantitative ELISA using recombinant ribonucleoprotein antigens. Clin Exp Immunol 1989;76: $172-7$

87 Guldner HH, Lakomek HJ, Bautz F. Anti-(U1)RNP and anti-Sm autoantibody profiles in patients with systemic rheumatic disease: differential detection of imunoglobulin $\mathrm{G}$ and $\mathrm{M}$ by immunoblotting. Clin Immunol Immunopathol 1986;40:532-8.

88 Field M, Williams DG, Charles $\mathrm{P}$, et al. Specificity of anti-Sm antibodies by ELISA for systemic lupus eythematosus: increased sensitivity of detection using purified peptide antigens. Ann Rheum Dis 1988;47:820-5.

89 Molden DP, Suzuki H, Nakamura RM. Assays for Sm and RNP antibodies: pitfalls and technical considerations. RNP antibodies: pitfalls an
Diagn Immunol 1985;3:24-8.

90 Vlachoyiannopoulos PG, Guialis A, Tzioufas G, et al. Predominance of IgM anti-U1RNP antibodies in patients with systemic lupus erythematosus. $\mathrm{Br} f$ Rheumatol 1996;35:534-41.

91 Snowden N, Hay E, Holt PJL, et al. Clinical course of patients with anti-RNP antibodies. F Rheumatol 1993;20: 1256-8.

92 Calderon J, Rodriguez-Valverde V, Sanchez Andrade S, et al. Clinical profiles of patients with antibodies to nuclear ribonucleoprotein. Clin Rheumatol 1984;3:483-92.

93 Tikly M, Burgin S, Mohanal P, et al. Autoantibodies in black South Africans with systemic lupus erythematosus: spec-
trum and clinical associations. Clin Rheumatol 1996;15: trum and

94 Hirohata S, Kosaka M. Association of anti-Sm antibodies with organic brain syndrome secondary to systemic lupus erythematosus [letter]. Lancet 1994;343:796.

95 Swaak AJ, Nossent JC, Bronsveld W, et al. Systemic lupus erythematosus. II. Observations on the occurrence of exacerbations in the disease course: Dutch experience with 110 patients studied prospectively. Ann Rheum Dis 1989;48: 455-60.

96 Satoh M, Yamagata H, Watanabe F, et al. Development of anti-Sm and anti-DNA antibodies followed by clinical manifestation of systemic lupus erythematosus in an elderly woman with long-standing Sjogren's syndrome. Lupus 1995;4:63-5.

97 Hoet RM, Koornneef I, de Rooij DJ, et al. Changes in anti-U1 RNA antibody levels correlate with disease activity in patients with systemic lupus erythematosus overlap synin patients with systemic lupus erythematosuritis Rheum 1992;35:1202-10.

98 ter Borg E, Horst G, Limburg P, et al. Shifts of anti-Sm specific antibodies in patients with systemic lupus erythematosus: analysis by countercurrentimmunoelectrophoresis, immunoblotting and RNAimmunoprecipitation. f Autoimmun 1991;4:155-64.

99 Yashuma M, Takasaki Y, Matsumoto K, et al. Clinical significance of $\mathrm{IgG}$ anti-Sm antibodies in patients with SLE. F Rheumatol 1990;17:469-75.

100 ter Borg EJ, Horst G, Limburg PC, et al. Changes in levels of antibodies against the $70 \mathrm{kDa}$ and a polypeptides of the U1RNP complex in relation to exacerbations of systemic lupus erythematosus. F Rheumatol 1991;18:363-7.

101 Habets WJ, de Rooij DJ, Holt MH, et al. Quantitation of anti-RNP and anti-Sm antibodies in MCTD and SLE by immunoblotting. Clin Exp Immunol 1985;59:457-66.

102 Arnett FC, Reveille JD, Moutsopolous HM, et al. Ribosomal P autoantibodies in systemic lupus erythematosus. Frequencies in different ethnic groups and clinical and immunogenetic associations. Arthritis Rheum 1996;39: immuno $1833-9$.

103 Isshi K, Hirohata S. Association of anti-ribosomal P protein antibodies with neuropsychiatric systemic lupus erythematosus. Arthritis Rheum 1996;39:1483-90.

104 Watanabe T, Sato T, Uchiumi T, et al. Neuropsychiatric manifestations in patients with systemic lupus erythematosus: diagnostic and predictive value of longitudinal examination of anti-ribosomal $\mathrm{P}$ antibody [see comments]. Lupus 1996;5:178-83.

105 Agius MA, Chan JW, Chung S, et al. Role of antiribosomal $\mathrm{P}$ protein antibodies in the diagnosis of lupus isolated to the central nervous system. Arch Neurol 1997;54:862-4.

106 West SG, Emlen W, Wener MH, et al. Neuropsychiatric lupus erythematosus: a 10-year prospective study on the lupus erythematosus: a 10-year prospective study
value of diagnostic tests. Am $\mathcal{F}$ Med 1995;99:153-63.

107 Iverson GL. Are antibodies to ribosomal P proteins a clinically useful predictor of neuropsychiatric manifestations in patients with systemic lupus erythematosus. Lupus 1996;5: $634-5$

108 Press J, Palayew K, Laxer RM, et al. Antiribosomal P antibodies in pediatric patients with systemic lupus erythematosus and psychosis. Arthritis Rheum 1996;39:671-6.

109 Sato T, Uchiumi T, Ozawa T, et al. Autoantibodies against ribosomal proteins found with high frequency in patients with systemic lupus erythematosus with active disease. $\mathcal{F}$ Rheumatol 1991;18:1681-4.

110 Long AA, Denburg SD, Carbotte RM, et al. Serum lymphocytotoxic antibodies and neurocognitive function in
systemic lupus erythematosus. Ann Rheum Dis 1990;49: 249-53.

111 Escalante A, Brey RL, Mitchell BDJ, et al. Accuracy of anticardiolipin antibodies in identifying a history of thrombosis among patients with systemic lupus erythematosus. Am F Med 1995;98:559-65.
112 Ghirardello A, Doria A, Ruffatti A, et al. Antiphospholipid antibodies (aPL) in systemic lupus erythematosus. Are they specific tools for the diagnosis of aPL syndrome [see comments]? Ann Rheum Dis 1994;53:140-2.

113 Gulko PS, Reveille JD, Koopman WJ, et al. Anticardiolipin antibodies in systemic lupus erythematosus: clinical correates, HLA associations, and impact on survival. F Rheumatol 1993;20:1684-93.

114 Merkel PA, Chang Y, Pierangeli SS, et al. The prevalence and clinical associations of anticardiolipin antibodies in a large inception cohort of patients with connective tissue diseases. Am f Med 1996;101:576-83.

115 Day HM, Thiagarajan P, Ahn C, et al. Autoantibodies to beta2-glycoprotein I in systemic lupus erythematosus and primary antiphospholipid antibody syndrome: clinical correlations in comparison with other antiphospholipid antibody tests. F Rheumatol 1998;25:667-74.

116 Abu-Shakra M, Urowitz MB, Gladman DD, et al. The significance of anticardiolipin antibodies in patients with lupus nephritis. Lupus 1996;5:70-3.

117 Bhandari S, Harnden P, Brownjohn AM, et al. Association of anticardiolipin antibodies with intraglomerular thrombi and renal dysfunction in lupus nephritis. Qf Med 1998;91: $401-9$.

118 Ogasawara M, Aoki K, Matsuura E, et al. Anti-beta 2 glycoprotein I antibodies and lupus anticoagulant in patients with recurrent pregnancy loss: prevalence and clinical significance. Lupus 1996;5:587-92.

119 Tomer Y, Viegas OA, Swissa M, et al. Levels of lupus autoantibodies in pregnant SLE patients: correlations with disease activity and pregnancy outcome. Clin Exp Rheumatol 1996;14:275-80.

120 Buttgereit F, Grunewald T, Schuler-Maue W, et al. Value of anticardiolipin antibodies for monitoring disease activity in systemic lupus erythematosus and other rheumatic diseases. Clin Rheumatol 1997;16:562-9.

121 Cooper RC, Klemp P, Stipp CJ, et al. The relationship of anticardiolipin antibodies to disease activity in systemic lupus erythematosus. Br F Rheumatol 1989;28:379-82.

122 Tsutsumi A, Matsuura E, Ichikawa K, et al. Antibodies to beta 2-glycoprotein I and clinical manifestations in patients with systemic lupus erythematosus [see comments]. Arthriis Rheum 1996:39:1466-74.

123 Jennings I, Kitchen S, Woods TA, et al. Potentially clinically important inaccuracies in testing for the lupus nticoagulant: an analysis of results from three surveys of the UK national external quality assessment scheme (NEQAS) for blood coagulation. Thromb Haemost 1997;77: 934-7.

124 Becker GJ, Waldburger M, Hughes GR, et al. Value of serum C-reactive protein measurement in the investigation of fever in systemic lupus erythematosus. Ann Rheum Dis 1980;39:50-2.

125 Hind C, Ng SC, Feng PH. Serum C-reactive protein measurements in the detection of intercurrent infection in oriental pateints with SLE. Ann Rheum Dis 1985;44:260-1.

126 ter Borg E, Horst G, Limburg P, et al. C-reactive protein levels during exacerbations and infections in SLE: a prospective longitudinal study. F Rheumatol 1991;17:16428.

127 Zein N, Ganuza C, Kushner I. Significance of C-reactive protein elevation in patients with SLE. Arthritis Rheum 1979;22:7-12.

128 Aderka D, Wysenbeek A, Engelmann $\mathrm{H}$, et al. Correlation between serum levels of soluble tumor necrosis factor receptor and disease activity in systemic lupus erythematosus. Arthritis Rheum 1993:36:1111-20.

129 Wolf RE, Brelsford WG. Soluble interleukin-2 receptors in systemic lupus erythematosus. Arthritis Rheum 1988;31: 729-35.

130 Inman R, Fong J, Pussel B, et al. The C1q binding assay in SLE: discordance with disease activity. Arthritis Rheum $1980 ; 23: 1282-6$

131 Abrass CK, Nies KM, Louie JS, et al. Correlation and predictive accuracy of circulating immune complexes with disease activity in patients with systemic lupus erythematosus. Arthritis Rheum 1980;23:273-82.

132 Buyon JP, Tamerius J, Belmont HM, et al. Assessment of disease activity and impending flare in patients with systemic lupus erythematosus. Comparison of the use of complement split products and conventional measurements of complement. Arthritis Rheum 1992;35: 1028-37.

133 Valentijn RM, van Overhagen $\mathrm{H}$, Hazevoet HM, et al. The value of complement and immune complex determinations in monitoring disease activity in patients with systemic lupus erythematosus. Arthritis Rheum 1985;28: 904-13.

134 Esdaile JM, Joseph L, Abrahamowicz M, et al. Routine immunologic tests in systemic lupus erythematosus: is there a need for more studies? $\mathcal{F}$ Rheumatol 1996;23: $1891-6$

135 Weinstein A, Bordwell B, Stone B, et al. Antibodies to native DNA and serum complement (C3) levels. Application to diagnosis and classification of systemic lupus erythematosus. Am f Med 1983;74:206-16.

136 Harkiss GD, Hazleman BL, Brown DL. A longitudinal study of circulating immune complexes, DNA antibodies and complement in patients with systemic lupus erythematosus: an analysis of their relationship to disease activity. $\mathcal{F}$ Clin Lab Immunol 1979;2:275-83. 
137 Uko G, Christiansen FT, Dawkins RL. Serum C4 concentration in the monitoring of systemic lupus erythematosus:
requirement for C4 allotyping. Rheumatol Int 1986;6:111requirer 14 .

138 Baqi N, Moazami S, Singh A, et al. Lupus nephritis in children: a longitudinal study of prognostic factors and therapy. F Am Soc Nephrol 1996;7:924-9.

139 Sullivan KE, Wisnieski JJ, Winkelstein JA, et al. Serum complement determinations in patients with quiescent systemic lupus erythematosus. F Rheumatol 1996;23: 2063-7.

140 Wild G, Watkins J, Ward AM, et al. C4a anaphylatoxin levels as an indicator of disease activity in systemic lupus erythematosus. Clin Exp Immunol 1990;80:167-70.

141 Negoro N, Okamura M, Takada T, et al. Clinical significance of $\mathrm{iC} 3 \mathrm{~b}$ neoantigen expression in plasma of patients with systemic lupus erythematosus. Arthritis Rheum 1989;32:1233-42.

142 Manzi S, Rairie JE, Carpenter AB, et al. Sensitivity and specificity of plasma and urine complement split products as indicators of lupus disease activity. Arthritis Rheum as indicators of 1 .

143 Gawryl MS, Chudwin DS, Langlois PF, et al. The terminal complement complex, C5b-9, a marker of disease activity in patients with systemic lupus erythematosus. Arthritis Rheum 1988;31:188-95.
144 Sjoholm AG, Martensson U, Sturfelt G. Serial analysis of autoantibody responses to the collagen-like region of $\mathrm{C} 1 \mathrm{q}$, collagen type II, and double-stranded DNA in patients with systemic lupus erythematosus. F Rheumatol 1997;24: $871-8$

145 Gunnarsson I, Ronnelid J, Huang YH, et al. Association between ongoing anti-C1q antibody production in peripheral blood and proliferative nephritis in patients with active systemic lupus erythematosus. Br f Rheumatol 1997;36:32-

146 Siegret C, Daha M, Westedt ML, et al. IgG autoantibodies against $\mathrm{C} 1 \mathrm{q}$ are correlated with nephritis, hypocomplementaemia, and dsDNA antibodies in SLE. F Rheumatol 1991;18:230-34

147 Chan TM, Cheng IKP. A prospective study on antiendothelial cell antibodies in patients with systemic lupus erythematosus. Clin Immunol Immunopathol 1996;78:41-6.

148 Scnabel A, Csernok E, Isenberg DA, et al. Antineutrophil cytoplasmic antibodies in systemic lupus erythematosus. Prevalence, specificities, and clinical significance. Arthritis Rheum 1995;38:633-7.

149 Isenberg DA, Garton M, Reichlin MW, et al. Long-term follow-up of autoantibody profiles in black female lupus patients and clinical comparison with Caucasian and Asian patients. Br F Rheumatol 1997;36:229-33. 